\title{
Best Practice Leadership of The Principal in Covid-19 Prevention Primary School at SD Muhammadiyah
} Purbayan

\section{| Ulva Dian Citra Resmi ${ }^{1, *}$ | Enung Hasanah ${ }^{2}$ |}

1,2 Magister of Educational Management, Universitas Ahmad Dahlan, Yogyakarta, Indonesia.

*citraresmi152@gmail.com

\begin{abstract}
This research aims to determine how the principal carried out his duties in handling covid 19 transmissions in SD Muhammadiyah Purbayan. This study uses a descriptive qualitative method. The data collection techniques are carried out with interviews, observations, and literature studies. Interviews were conducted with teachers and employees of SD Muhammadiyah Purbayan Yogyakarta. Participants in this interview were selected through several criteria, including teachers and school employees directly involved by the school principal in covid-19 prevention. The validity of the data used is the triangulation technique. Data analysis techniques used are data reduction, data presentation, and conclusions. The results of this study show that; 1) the principal of SD Muhammadiyah Purbayan took steps to prevent transmission of the COVID 19 virus; 2) principals of schools which matters during the pandemic; 3) organizing school principals, assignments and to teachers and employees; 4) the principal together with teachers and employees from outside the school carry out activities which are planned, and 5) the principal of the hall which is the activity. KEYWORDS

Management; principal; COVID-19; elementary school.
\end{abstract}

\section{INTRODUCTION}

In early 2020, the world was hit with news of the Coronavirus or Covid-19 virus outbreak in China and has spread to more than 121 countries. The virus was first discovered in Wuhan, China, in December 2019. Although the disease's cure rate is more than half the number of infected cases, the new type of coronavirus first discovered in Wuhan has killed more than 4,000 people. On Wednesday (11/3/2020), the World Health Organization (WHO) stated that the new type of coronavirus causing Covid-19 had become a global pandemic (http://kompas.com/) .

The virus disrupts the respiratory tract like the common flu. Symptoms are cough, runny nose, fever, headache, and shortness of breath. The virus is not very dangerous if it infects people under the age of 40 and has an excellent immune condition, but in older adults and sufferers who have congenital diseases such as heart, hypertension, sugar, lungs, then the result can be fatal, i.e., death. Transmission of this COVID-19 virus can be through the larynx's droplet infected with the virus when he coughs, sneezes, spits, or talks. President Joko Widodo announced that two Indonesians were positively infected with COVID-19 on March 2, 2020. From then on, the government made various preventive efforts. Patients are positive, people under supervision (ODP) and patients in supervision (PDP) continue to grow every day.

The central and local governments urged the public to reduce outdoor activities, including the city of Yogyakarta. That is due to the virus's transmission very easily and quickly through 
a positive person's droplet when he coughs, sneezes, spits, or talks. All lines are affected by this pandemic, including education aspect in Yogyakarta. The number of students in Yogyakarta area encourages local governments and related parties to take emergency policies. An education policy that is taken, socialized to the essential leadership that is the principal. The leadership role of the principal is indispensable in the implementation of policies during this COVID-19 emergency. In this pandemic, the agency's head is the main factor that can be solved by problems arises.

Based on its official statement, alternatives pursued by the Indonesian government through the Ministry of Education and Culture are ready with all scenarios, including implementing cooperation to encourage online learning for students. Following the circular letter of the Ministry of Education and Culture No. 36962 / MPK. A / HK / 2020 related online learning and working from home to prevent Coronavirus spread (COVID-19). The policy is an effort to keep students at home. The Ministry of Education and Culture (Kemendikbud) is preparing some support to speed up the process. The Ministry of Education and Culture develops remote learning apps based on portals and android and other learning houses.

The World Bank says that the Covid-19 pandemic is now threatening and potentially making educational outcomes worse. Pandemics have had a significant impact on education by closing schools almost everywhere in the world. However, it is possible to overcome these shocks and to turn a crisis into an opportunity. The first step is to successfully address school closures by protecting health and safety and preventing students from losing learning using distance learning. At the same time, states need to start planning school reopening. That means preventing dropouts, ensuring healthy school conditions, and using new techniques to promote rapid learning recovery in crucial areas once students return to school (World Bank, 2020).

The Pandemic situation is where a school principal's significant role is to continue to exercise his leadership well during a crisis like this. Principals are required to implement "crisis management," which is the process of preparing and managing emergency or unforeseen situations that affect students, teachers, staff, and stakeholders. Leadership is an essential component of Public Relation (PR). It differs from risk management, which requires principals to assess potential threats and find the best way to avoid such threats. In crisis management, this threat is already happening and must be faced (Fernandez et al., 2020).

Schools' readiness to carry out online learning by utilizing technology as an online learning medium is not easy to implement because of the many obstacles that hinder learning run effectively. Economic problems are an obstacle that arises in students of SD Muhammadiyah Purbayan because online learning using the internet requires money to buy data packages. Another problem that arises is the difficulty of the internet network; not all schools are connected to the internet, so teachers who use the internet network are less stable. Schools, as educational institutions, have a responsibility to ensure learning activities run safely. The existence of COVID-19 requires schools to take policies to deal with or prevent the transmission of the COVID-19 virus. So that students can still carry out their learning well without feeling anxious and anxious. The principal, as a decision-maker, has a significant role in the handling of the Covid-19 virus for the sake of student safety and continuity of learning (Chaudari et al., 2020).

A policy is a written rule that is a formal decision of the organization, which is binding, governing behavior to create a new system of values in society. The policy will be the primary reference of members of the organization or public members in behaving. Whereas according to the United Nations, as cited by Solichin (2014), a policy is an action guide. The 
guidelines could be very simple or group, general or specific, broad or narrow, vague or clear, loose or detailed, qualitative or quantitative, public or private. In this sense, a policy may be a declaration of a necessary code of action, a specific course of action, a program concerning a particular activity, or a plan.

Iskandar (2013) explained that a principal is essentially a planner, organizer, leader, and controller. A principal's existence is necessary to achieve a set goal in which in the organization, he leads develops a wide range of knowledge and organizations that become a place to nurture and develop human resource careers. An organization or institution needs a leader to run management in order to achieve its goals. In education, schools need a leader to manage the school's ability to run correctly. As a school leader, the principal should have a good leadership spirit to effectively and efficiently achieve the school's educational objectives.

Ted, et al. (Kartono, 2003) explains that the understanding of leadership is that activities or art influence others to cooperate based on the person's ability to guide others in achieving the goals that the group wants. According to Young (in Kartono, 2003), leadership is a form of dominance based on personal abilities that can encourage or invite others to do something based on acceptance by their group and have the right specialist skills.

The skills that innovative leadership must have are expertise in managerial and leadership. Managerial expertise is required for leaders to be able to handle the complementary compliment of education. Educational leadership skills are needed to obtain innovative leaders in leading educational institutions to conform to educational autonomy (Sham, 2012). One of the essential factors in achieving educational goals in schools is the leadership of the principal. Referring to their functions and roles, principals serve as managers and education leaders. Effective management and leadership require principals who realize that their role is critical in policy determination.

The principal has a vital role in leading, planning new policies in the emergency response period, organizing all of his subordinates, distributing duties, and carrying out tasks as planned and all school residents. The principal must also control implementing new policies to be implemented correctly and achieve the planned goals. During this pandemic, principals should be able to share their leadership with teaching staff and employees based on their respective abilities, establish interpersonal relationships, develop justice and responsible principles, and be able to work in teams, so that new policies in times of emergency response can be implemented smoothly and educational goals can be achieved.

This research aims to determine how the principal's management in dealing with the prevention of Covid-19 transmission in the school environment so that school residents' health and safety can be protected. This research was conducted at SD Muhammadiyah Purbayan, located at Jalan Purbayan 11, Kotagede Sub-district of Yogyakarta. SD Muhammadiyah Purbayan Kotagede Yogyakarta is a private school geographically located in Yogyakarta city in the southern corner, which borders Bantul Regency. SD Muhammadiyah Purbayan has 442 students and 26 teachers, and 17 employees. Teachers, employees, and students of SD Muhammadiyah Purbayan are from Yogyakarta area but come from other districts such as Sleman and Bantul. The school's geographical location status is also the origin or domicile of the school residents. The research background on the principal's management in handling covid-19 transmission prevention in the school environment was conducted in SD Muhammadiyah Purbayan Kotagede Yogyakarta. 


\section{RESEARCH METHODS}

This study employed narrative inquiry approach to investigate the teacher's beliefs and experience towards web-based learning. Barkhuizen (2014) stated that narrative research is a research design in which storytelling is used as data or a means for data analysis and findings. In the study, the story which was obtained from participant used as main data.

The participant of this study was selected purposively based on the research objective. The English teacher at a non-formal school in Central Java was selected since the participant had their own experience and used the official website from Education Ministry of Indonesia. At the first time, the teacher only taught English by using traditional method and also some media, such as whiteboard, books, and worksheets. Then, in the middle of 2019, the teacher started to use technology such as google form. The teacher had used the google form for making exercise and homework. In August 2019, the teacher got the training to use the web-based learning from the government. The website is http://www.setara.kemdikbud.go.id. The teacher has used the web-based learning for the English teaching learning process for 1 year. Those are the rationale of choosing an individual participant. Barkhuizen (2014) mentioned that the participant is the main character in any narrative inquiry. The study will contain participant's life experiences regarding her beliefs and experience towards web-based learning which was represented as the report.

For obtaining the data, the researchers carried out semi-structured interview and document analysis. The researchers took the data from the participant. The interview design was adopted from the theory of beliefs from Richard and lockhart (1994). There were 20 questions consisted of four aspects of teacher's belief. Then, the researcher recorded and transcribed the interview attentively to gain the verified data.

In this study, the data which have been collected were coded and analyzed using Thematic Analysis Single Case Studies. The model of thematic analysis is proposed by Barkhuinzen et al., (2014) which consists of single case studies and multiple case studies. For this study, the researcher used a single case study to analyze the data from an individual participant. Moreover, Barkhuinzen proposed three main activities in the thematic analysis (Barkhuinzen et al., 2014). Firstly, repeatedly reading of the data. Secondly, coding and categorizing the data extracts and the last recognizing the thematic headings. The process of data analysis was begun by listening cautiously to the recording of the participant's interview. After listening several times, the interview was trascripted. The data were read repeteadly to get deeper understanding. Then the data were analyzed and categorized based on the themes. Furthermore, to get trustworthiness, the researcher also conducted triangulation method. The researcher also got the data by interview and document analysis. It was included in the method triangulation. On the other hand, member checking is a process in which the researcher asked one or more participants to check the accuracy of the account. Thus, the researcher asked the participants after transcribing the interview; whether the transcription of the participants' answers were correct or not.

This study uses qualitative descriptive method with case study model. Descriptive Qualitative Methodology is a research procedure that produces descriptive data in written or oral words from people and observable behavior. This approach leads to Moelong's holistic (intact) individual background (2009). So in this study, the case study approach will be used to uncover the principal's role in preventing Coronavirus (COVID-19) transmission in SD Muhammadiyah Purbayan. The researchers investigate thoroughly and carefully the programs, events, activities, and processes of a group of individuals. Cases are limited by time and activity, and researchers collect information in full using data collection methods (interviews, observations, documents) based on the specified time. Researchers explore 
descriptive quantifiable phenomena (Sugiyono, 2010). This research aims to examine the problem and gain more in-depth meaning according to the problem's study. The underlying consideration used in this type is that such cases will obtain further and in-depth knowledge scientifically (Nasution, 2008).

The sample used is purposive sampling with a single-stake case study technique. According to Arikunto (2006), purposive sampling takes samples based not on random, regional, or strata, but rather on considerations that focus on a particular purpose. Notoatmodjo (2010) said the definition of purposive sampling is sampling based on specific considerations such as population traits or previously known traits.

Based on the experts' understanding, it can be concluded that researchers more appropriately use purposive sampling if a study requires specific criteria so that samples taken later by the purpose of the study can solve research problems and provide more representative value. In applying this technique, it is necessary to apply the steps, namely; (1) determine the purpose of the research, whether it requires specific criteria, so as not to occur bias; (2) researcher determines the criteria; (3) look for population and sample; and (4) identify the minimum number of samples that will be used as research subjects and have met the criteria. The terms of use of this technique include; (1) criteria or restriction stipulated carefully; and (2) sample taken as a research subject is a sample that meets the specified criteria.

In this study, the participants were teachers and employees of SD Muhammadiyah Purbayan Kotagede Yogyakarta. Participants are determined based on specific criteria, which can meet the research objectives, teachers and employees directly involved by the principal in dealing with covid-19 transmission prevention in his school, namely teachers or employees included in the school-level COVID-19 task force team. The fulfillment of these criteria is expected that the interview results with the participants will obtain data following the research objectives.

Data collection techniques are carried out with interviews, observations, and literature studies. Furthermore, data validity is carried out using triangulation techniques, namely source triangulation and triangulation methods. The data collection techniques in this study were conducted with in-depth interviews. Techniques and instruments in research are essential things in research because it concerns the validity of the data to be obtained as the research results' embodiment.

Interviews were conducted privately between researchers and participants who had been selected according to specific criteria. Before conducting the interview, the researchers prepared questions that will be asked to participants who can support obtaining data according to the study's purpose. The interview's timing was agreed upon between the researcher and the participants by conducting communication to determine the interview schedule to not interfere with the participant's primary task. Interviews were conducted between 30 - 45 minutes per participant.

Tabel 1. Interview Instruments

\begin{tabular}{cl}
\hline Number & \multicolumn{1}{c}{ Indicators } \\
\hline 1 & $\begin{array}{l}\text { Preparation of what schools do in countering covid-19 transmission to school } \\
\text { residents. }\end{array}$ \\
2 & $\begin{array}{l}\text { People who is involved in tackling COVID-19 transmission. } \\
3\end{array}$ \\
& $\begin{array}{l}\text { The time of implementation of the covid-19 transmission prevention program against } \\
\text { school residents. } \\
\text { Locations of particular concern in efforts to prevent or combat covid-19 transmission } \\
\text { to school residents. }\end{array}$
\end{tabular}


5 The reason for the implementation of covid-19 transmission program efforts against school residents.

The school's way of preventing or tackling covid-19 transmission to school residents.

Observations and literature studies were conducted to look for additional data supporting the data obtained from interviews between participants and previously selected participants based on specific criteria. Field observation is conducted by observing schools, facilities, and infrastructure facilities used to prevent COVID-19 transmission. This observation is done to photograph how the facilities are suitable. Researchers also conducted observations on school documents related to the prevention of COVID-19 transmissions, such as emergency curriculum documents during pandemics, teacher administration based on emergency curriculum, and school learning implementation guidelines and activities compiled by the school-level COVID-19 task force team.

This research data analysis technique uses qualitative analysis with an interactive analysis model. To determine the validity of the data, the researchers triangulated the data. Triangulation is a data validity technique that utilizes other things beyond that power to check or compare to the original data of the research results (Moleong, 2009). In this study, researchers took the step of triangulating the source to obtain validation from the research data obtained until the data was saturated. If the data has been validated from various sources, it can fulfill the construct to withdraw conclusions.

Researchers analyzed the data with three steps: data reduction, data display, and conclusion withdrawal (Sugiyono, 2010). In the first step, data reduction, researchers collect all the data from in-depth interviews, observations, and literature studies or documents. The data collection results are created as a comparison in seeking validation of the data that has been obtained. The research data results were separated and processed following the research indicators on the leadership of the principal in the handling of covid-19 transmission prevention and programs designed by the school. The results of all data processing are before summarized into an infographic or diagram explaining the indicators that have been determined by the researcher. The presentation of data done with tables and diagrams created by researchers then becomes a means to determine the conclusions of the research that has been done.

\section{RESULTS AND DISCUSSION}

\section{Headmaster's Leadership in Dealing with Covid-19 Transmission at Muhammadiyah Purbayan Elementary School}

In the effort to prevent the transmission of the Covid-19 virus in SD Muhammadiyah Purbayanand the implementation of learning during the Covid-19, the principal as the principal has a vital role in decision making in order to protect the safety of all school residents, both students, educators and employees and the implementation of learning continues to run effectively. The principal makes decisions or policies through internal meetings and coordinates with teachers and employees of SD Muhammadiyah Purbayan regarding distance learning policies that the school will run. The learning policies refer to a circular letter from the Ministry of Education and Culture, a circular letter from the Governor of Yogyakarta Special Region, a circular from the Education Office of the Special Region of Yogyakarta province he leaned a circular letter from the Yogyakarta City PdM. After receiving the circular, the school followed up the circular coming out from above and then issued a circular (SE) from the principal. The savagery carried out by the principal of SD 
Muhammadiyah Purbayan Utnuk to solve the problem is through 2 ways: 1) the policy of studying at home; 2) form a covid-19 task force.

\section{Learning from Home Policy}

Schools as education organizers should be careful and ready to take appropriate steps during the Covid-19 pandemic. Efforts - the school's efforts to prevent the transmission of coronavirus (Covid-19) in SD Muhammadiyah Purbayan is to divert the teaching-learning process that was initially implemented in the school diverted to Remote Learning (PJJ) by the circular number of the Ministry of Education and Culture (Kemdikbud, 2020). 36962 / MPK. A/HK/2020 related distance learning and working from home to prevent Coronavirus spread (COVID-19). If there is a task that must be collected by the student's guardian to the school, at the time of the collection, it becomes several waves. So, no crowd at school. It is following the Decree of the Minister of Health [29] of the Republic of Indonesia Number Hk.01.07 / Menkes / 382/2020 on Public Health Protocols in Place and Public Facilities in the Framework of Prevention and Control of Coronavirus (COVID-19), which contains the protection of the health of individuals using personal protective equipment in the form of masks covering the nose and mouth to the chin. If people need to leave the house or interact with others whose health status is unknown (which is likely to transmit COVID-19), clean your hands regularly by washing your hands using soap under running water or using a hand sanitizer alcohol and maintain a minimum distance of 1 meter from others to avoid drips from people who are talking, coughing or sneezing, and avoid the crowd. The principal monitors the implementation of distance learning through online communication, with a duration of once a week. Through the Standard Coordinator process, the principal requested a weekly report on the implementation of distance-learning, the principal, and the standard process of evaluating the report submitted by each class. If there are any obstacles, immediately communicate with the class so that the distance learning process can run properly. The school also does not carry out the Final Examination of Regional Schools (UASDA) following the Ministry of Education and Culture circular letter number 4 of 2020 on the Implementation of Education in the Event of Coronavirus (COVID-19) Emergency.

\section{Establishing a Covid Task Force}

The principal formed a school-level Covid-19 task force consisting of teachers, employees, and the surrounding community. The principal with the task force made rules for all school residents to always comply with health protocols, namely by checking body temperature, washing hands with soap and running water, wearing masks, keeping distance with others at least 1 meter. The school procures the infrastructure facilities needed to implement health protocols in the form of the addition of sinks, thermoguns, hand wash soaps, tissues, disinfectant fluids, disinfectant sprayers, masks, hand sanitizers, and face shields. Periodically, the school conducts disinfectant fluid spraying throughout the school environment, including all classrooms. The principal monitors the health of all school residents every week, communicating with them via WhatsApp group. Besides, the principal made a policy of implementing teachers and education personnel's duties during the pandemic with a system of shifts or pickets alternately, a maximum of 50\% attendance of all teachers and education personnel every day, starting from 08.00-13.00. Picket schedules are arranged in line with the school's staffing section. It is following the circular letter from the Regional Leader of Muhammadiyah City of Yogyakarta, No. 226/III.0/A/2020.

Leadership is needed in the principal as a perpetrator in the world of education. A principal is both a leader and a manager. As a leader of an institution, the principal must have a good leadership spirit in carrying out his duties as a leader. The principal's leadership 
is required to start getting a job as a principal. The principal's leadership is instrumental in the successful implementation of programs that have been planned to achieve the educational goals in that school. When implementing programs that fit the original plan, the leadership qualities of the principal are also needed in decision-making in times of emergency and incidental. The principal in making decisions is included in the managerial competency. Vincent (2008) suggests that the manager is the one who does things right (the person who does things right), the manager's job is to plan, organize, organize, coordinate and control to achieve the specified goals. As a manager, the principal's job is to plan, organize, organize, coordinate, and control to achieve the goals set by carrying out management functions.

Before making a decision, the principal considers the situation and conditions that occur. In this relationship, the principal (manager) 's decision is the way of acting chosen by the manager as the most significant step to solve a problem or achieve a goal. In this case, the principal (manager) 's decision is the way of acting chosen by the manager as the most significant step to solve a problem or achieve the goal. Decision-making, according to Robert \& Kinicki (2008), is to propose when managers use a rational four-step sequence when making decisions: (1) identify the problem, (2) generate an alternative, (3) choose a solution, and (4) implement and evaluate the solution. Gregory \& Margareta (1998) explained in his research that the decision was to respond to problems. Issues can vary in their interests, from figuring out which job should accept after graduation to deciding which brand of toothpaste should buy. Decision making is very important for the principal because the decision-making process has a role to play in moving, communicating, and motivating his subordinates. Principals must have the skills to make decisions quickly, appropriately, effectively, and efficiently to achieve educational goals.

Terry et al. (2010) explained that management functions could be divided into four parts: planning, organizing, driving, and control. It follows the principal's duties during the implementation of Distance Learning (PJJ) during the pandemic. In the implementation of distance learning, the principal plans the PJJ program, organizes teachers and employees in LFH training, conducts distance learning together with all teachers, and monitors and evaluates the implementation of PJJ during the Covid-19 pandemic.

As of now, Indonesia is facing a Covid-19 virus that has infected several people. Some areas have become red zones of transmission of this virus. Every day the number of Indonesians who are declared positively infected is increasing, and the increase is increasing. It has been the driver of almost all Indonesia regions eliminating face-to-face learning of schoolchildren for a while. Including Yogyakarta as a Student City is also affected. Some foundation schools eliminate face-to-face learning to anticipate the transmission of the Covid-19 virus by minimizing direct contact between school residents. In response to this situation, in the world of education, the principal needs to take the right policy to lead his institution because with the right policies and efforts can have a good impact on the sustainability of the institution he leads and vice versa. If the principal does not have good quality in his leadership in taking policy in the event of an emergency, it will be fatal to his institution's condition.

The principal in an emergency, always thinking calmly but alertly. A calm mind will make it easier to find a solution to a problem. As a leader in an institution, the principal should pay attention to several things as references or considerations in policymaking. Schools have structural relationships with other institutions on it, so making decisions should consider the institutions' recommendations above it, e.g., the Education Office or its Foundation. The principal must consider the school's condition, the teacher's condition, and the students' condition so that taking the policy can be beneficial for all. 
The principal communicates well to convey the policy of the Office or foundation to parents in order to be accepted, condoned, and implemented directive. In addition to delivering student-related policies, principals must also take preventive measures independently, such as 1)Eliminate face-to-face learning activities, be replaced with distance learning, learn from home-each by online, offline, or self-study doing the work of the teacher. 2) Encourage all school residents always to drink vitamin C, exercise regularly, wash hands properly using soap and running water, 3) Do social and physical distancing, avoid going in crowded places, avoid direct contact with others such as shaking hands, cuddling, etc., as well as avoiding using public transportation, 4) Doing spraying school environments with disinfectant fluids periodically, 5) Providing hand sanitizer and hand soap in every sink and restroom. 6) Digging into information from various sources related to the Covid-19 virus, 7) Creating a calm atmosphere for all school residents, 8) Conducting good communication with all parties, both agencies, foundations, local communities, school committees, and parents to communicate important matters related to the handling of Covid19 transmission, which requires immediate handling and requires collaboration and coordination of all parties. With the implementation of distance learning, there are several steps taken by the school, namely: Compiling the curriculum supplement of the covid-19 pandemic/ emergency period, mapping the ability of knowledge and use of technology, fulfillment of the teacher's knowledge and ability about technology, the fulfillment of the teacher's understanding of the material, involving parents and the community in the process of distance learning, parents and the community must take optimal portions and positions when learning in the school cannot be carried out, with the ability of the principal in communicating the message well, building collegiality between teachers and employees as well as to the parents, to be able to jointly implement the policy as a determinant of the success of the mission vision in tackling covid-19 virus transmission at the education unit level.

\section{CONCLUSION}

The results of the above discussion can be concluded that; 1) the principal of SD Muhammadiyah Purbayan implemented measures to prevent the transmission of covid 19 viruses; 2) the principal plans things to do during the pandemic; 3) the principal organizes, distributes duties and leadership to teachers and employees; 4) the principal along with teachers and employees and outside the school carry out the activities that have been planned, and 5) the principal conducts control over the activities carried out.

\section{REFERENCES}

Aneta. (2010). Implementation of urban poverty reduction program (P2KP) policy in gorontalo city. Journal of Public Administration. Vol. 1, 1.

Arikunto, S. (2006). Research Methodology. Yogyakarta: Bina Aksara.

Fernandez, A.A, et al. (2020). Academic Leadership in a Time of Crisis: The Coronavirus and COVID-19. Journal of Leadership Studies 14 (1), https://doi.org/10.1002/jls.21684.

Gregory, N.B. \& Neale, M.(1994). An Organizational behavior. New York: lizwiddicombe. Hasbullah, H.(2015). Education Policy: in the Perspective of Educational Objective Theory, Application, and Conditions in Indonesia. Jakarta: Raja Grafindo Persada.

Huang, C., et al. (2020). Clinical features of patients infected with 2019 novel coronavirus in Wuhan, China. The Lancet 395 (10223) (2020): 497-506. https://doi.org/10.1016/S0140-6736(20)30183-5

Iskandar, U. (2013). Principal leadership in improving teacher performance. Journal of Educational Science Vision. 
John, A. (2008). Motivating Leadership. Jakarta: Gramedia Pustaka Utama.

Ministry of Health. (2019) Number Hk.01.07 / Menkes / 382/2020. About health protocols for the public in places and public facilities prevent and control coronavirus (COVID19). Jakarta: Ministry of Health.

Ministry of Health. (2020). Number HK.02.01 / Menkes / 202/2020 About Self Isolation Protocol in The Handling of Coronavirus (Covid-19). Jakarta: Ministry of Health.

Ministry of Education and Culture. 36962 / MPK. A/HK/2020. About learning online and working from home to prevent the spread of Coronavirus (COVID-19). Jakarta: Ministry of Education and Culture.

Ministry of Education and Culture. (2020). Circular Letter number 4, the year 2020. The Implementation of Education Policy in The Emergency of The Spread of CoronaVirus Disease (Covid-19). Jakarta: Ministry of Education and Culture.Kern, R. (2000). Literacy and Language Teaching. New York: Oxford University Press.

Kompas. (2020). Corona Handling Protocol in Education. Retrieved from https://edukasi.kompas.com/read/2020/03/10/17441171/15-protokol-

HasimandHasanah-penanganan-virus-corona-di-areapendidikan-seperti-apa

Kreitner, R. \& Kinicki, A. (2008). Organizational behavior: key concepts, skill \& best practice. New York: McGraw-Hill.

Moleong, L. J. (2009). Qualitative Research Methodology. Revision Edition. Bandung: PT Remaja Rosdakarya

Nasution. (2008). Qualitative Research Methodology. Jakarta: Sinar Grafika.

Notoatmodjo, S. (2010). Health Research Methodology, Rineka Cipta. Jakarta. Indonesia.

Raymond, M. \& George P. S. (2012). Information Management System. Jakarta: Four Salemba.

Sentell, T., et al. (2020). Interdisciplinary Perspectives on Health Literacy Research Around the World: More Important Than Ever in a Time of COVID-19. International Journal of Environmental Research and Public Health. https://doi.org/10.3390/ijerph17093010.

Solichin, A.W. (2008). Analysis of Discretion from Formulation to Implementation of State Policy. Jakarta: Bumi Aksara.

States, United. (2008). The 2007 CIA World Factbook. United States: Al Haines.

Sugiyono. (2010). Qualitative Quantitative Research Methods and R\&D.Bandung: Alfabeta. Terry, R.G. \& Leslie, R.W. (2010). Fundamentals of management. Jakarta: Earth Literacy.

The COVID-19 Pandemic: Shocks to Education and Policy Responses. Diakses September 25, 2020. https://openknowledge.worldbank.org/handle/10986/33696.

Tilaar, H.A.R. \& Riant, N. (2009). Education Policy: Introduction to Understanding Education Policy and Education Policy as Public Policy. Yogyakarta: Pustaka Pelajar.

Vincent, G. (2008). Full Quality Management. Jakarta: PT. Gramedia Pustaka Utama. 